\title{
Behandling av akutt hjertesvikt
}

\author{
Enkelte medikamenter som brukes ved akutt hjertesvikt, kan forverre \\ tilstanden. Vasopressin bør brukes med stor forsiktighet.
}

Akutt hjertesvikt er fortsatt en tilstand med høy mortalitet. Behandlingen inkluderer inotrope medikamenter hos de mest kritisk syke.

- Disse medikamentene øker samtidig oksygenbehovet i myokard. Dette kan ytterligere forverre tilstanden, siden den akutte svikten hos de fleste er utløst av nedsatt oksygentilførsel til hjertet, slik man ser ved hjerteinfarkt, sier Stig Müller.

Behandlingen består ofte av en kombinasjon av medikamenter, inkludert inotrope

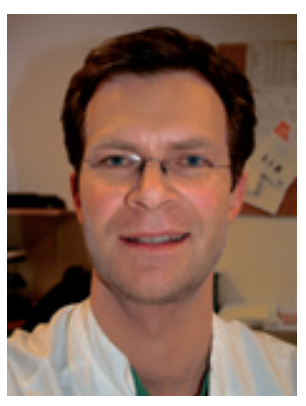

Stig Müller. Foto privat midler. Det kan derfor være vanskelig å bedømme hvert enkelt medikaments bidrag til hjertets kontraksjonskraft og oksygenforbruk. Müller har i sin avhandling brukt dyreeksperimentelle studier for å undersøke

effekten av ulike medikamenter som eneste behandling ved eksperimentelt utløst akutt hjertesvikt.

- Overraskende nok fant vi at levosimendan og dobutamin i lave doser øker hjertets kontraksjonskraft uten å øke oksygenbehovet nevneverdig. Den uheldige effekten av inotrope medikamenter virker å være doseavhengig. Vi fant også at vasopressin, en ren vasopressor, har potensielt farlige effekter i hjerter med nedsatt oksygentilførsel. Vasopressin bør derfor brukes med stor forsiktighet ved tilstander med nedsatt oksygentilførsel til hjertet, sier han.

Müller disputerte for ph.d.-graden 18.6. 2009 ved Universitetet i Tromsø, med avhandlingen Preclinical assessments of potential treatments for acute heart failure.

\section{Eline Feiring}

eline.feiring@legeforeningen.no

Tidsskriftet

\section{Ordforklaringer}

Inotrope medikamenter: Medikamenter som øker kontraksjonskraften i hjertet.

Vasopressin: Antidiuretisk hormon, et fysiologisk hormon som øker vannresorpsjonen i nyrene. I høyere konsentrasjoner er det en potent vasokonstriktor. Anvendes bl.a. ved alvorlige og langvarige sjokktilstander der blodårene mister evnen til sammentrekning.

Levosimendan: Virker inotropt gjennom kalsiumsensitisering og er perifert vasodilaterende.

Dobutamin: Virker inotropt gjennom $\beta$-adrenerg stimulering.

\section{Stamceller fra voksen hjerne}

\author{
Hjernen inneholder stamceller. Kunnskap om slike celler kan \\ bli viktig for behandling av både nevrodegenerative sykdommer \\ og hjernesvulster.
}

Hjernen har begrenset evne til å reparere skader, f.eks. ved nevrodegenerative sykdommer. Men den inneholder stamceller, som kan utvikle seg til modne nerveceller, også i voksen alder. I avhandlingen Neural stem cells from the adult human central nervous system and brain tumors. Properties in vivo following xenotransplantation viser Håvard Ølstørn at stamceller i hjernen kan brukes for å utvikle nye behandlingsformer.

- Vi har vist at stamceller fra voksen hjerne kan dyrkes i laboratoriet. Når de transplanteres inn i hjernen på rotter som er påført en hjerneskade, ser vi at mange celler overlever transplantasjonen og vandrer helt spesifikt inn i den skadede delen av hjernen. Noen av cellene begynte å utvikle seg til nye nerveceller. Vi håper at transplantasjon av pasientens egne hjernestam- celler kan benyttes som behandlingsmetode, sier Ølstørn.

Han har også vist at det finnes celler i hjernesvulster med egenskaper som likner hjernestamcellenes. Stamcellene i slike svulster kan ha betydning for at hjernesvulster faktisk oppstår og utvikler seg.

- Når stamceller fra hjernesvulster dyrkes i laboratoriet og transplanteres til musehjerner, oppstår det nye hjernesvulster. Studier av stamceller i hjernesvulster kan lede oss frem mot ny terapi for hjernekreft, hvor behandlingen rettes spesifikt mot kreftstamcellene, sier Ølstørn.

Han disputerte for ph.d.-graden ved Universitetet i Oslo 22.10. 2009.

\section{Anne Forus}

anneforu@online.no

Tidsskriftet

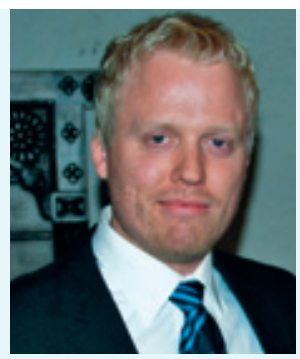

Håvard Ølstørn. Foto privat

\section{Ordforklaringer}

Xenotransplantasjon: Overføring av levende celler, vev eller organer mellom arter, f.eks. mellom dyr og mennesker.

Stamceller: Umodne celler som er selvfornyende og kan differensiere til ulike typer spesialiserte celler. Hjernestamceller kan f.eks. differensiere til nerveceller.

Nevrodegenerativ sykdom: Progredierende nevrologisk sykdom som fører til at hjerneceller gradvis dør. Eksempler er Parkinsons sykdom og Huntingtons sykdom. 